\title{
CRITICISM OF IDEAS OUT OF PLACE: THE ALBERTO TORRES' LEGAL
}

REALISM

\section{CRÍTICA ÀS IDEIAS FORA DE LUGAR: O REALISMO LEGAL DE ALBERTO TORRES}

\author{
Daniel Machado Gomes ${ }^{1}$ \\ Maurício Pires Guedes 2
}

\begin{abstract}
This article aims at exposing the legal ideas of Torres that architect a realistic theory of the law and to present the constitutionalism that emerges from the analysis of the author. The research uses the qualitative and deductive method, having as primary source and theoretical framework the work The National Organization. As a result, it was understood that Torres' legal realism provided new instruments for the application of legal norms and marks to this day the critique of legal formalism within studies of Theory of Law. It is concluded that from the time of Torres until 1988 there were many discussions that marked the development of Brazilian constitutional history that have their origin in the events that occurred at the national level, as teaches the author.
\end{abstract}

Key-words: Constitution of 1891; antiliberalism; nationalism; antiformalism; constitutionalism.

\section{RESUMO}

Este artigo tem como objetivo expor as ideias jurídicas de Torres que arquitetam uma teoria realista do direito, e apresentar o constitucionalismo que emerge da análise do autor. A pesquisa

\footnotetext{
${ }^{1}$ Pós-doutorado em História do Direito pelo IHGB (2019). Doutorado em Filosofia pelo IFCS, da UFRJ (2015). Mestrado em Ciencias Juridico-Civilísticas pela Universidade de Coimbra, Portugal (2003). Graduação em Direito pela UCP (1999). Desenvolve pesquisas na área de Teoria e História dos Direitos Humanos. É líder do grupo de pesquisa Lei, Justiça e Direitos Humanos no qual coordena o projeto "Direito e Direitos Humanos em Perspectiva". Atualmente é coordenador do Programa de Pós Graduação Stricto Sensu em Direito da UCP, lecionando na linha Fundamentos da Justiça e dos Direitos Humanos. Atua na Graduação em Direito desde 2000, ministrando as disciplinas de Filosofia do Direito, Direito Civil e Metodologia da Pesquisa. Universidade Católica de Petrópolis - Brasil. ORCID: https://orcid.org/0000-0003-0615-1814 Lattes: http://lattes.cnpq.br/5147053344281753 E-mail: daniel.machado@ucp.br

${ }^{2}$ Possui graduação em Direito pela Universidade Cândido Mendes (2002) e pós-graduação em Direito Público e Privado pela Escola da Magistratura do Estado do Rio de Janeiro (2007). É mestre em Direito pela Universidade Gama Filho - UGF (Capes 5) e doutorando em Direito pela Universidade Veiga de Almeida - UVA (Capes 4). É professor da graduação e convidado da pós-graduação da Universidade Católica de Petrópolis (UCP). É advogado, tendo exercido a função de procurador adjunto administrativo do Município de Petrópolis entre os anos de 20092012 e a função de assessor jurídico da secretaria de meio ambiente do Município de Petrópolis entre os anos de 2018-2019. É vice-diretor do Centro de Ciências Jurídicas da Universidade Católica de Petrópolis, coordenando o Curso de Direito. Universidade Católica de Petrópolis - Brasil. ORCID: https://orcid.org/0000-0002-9521-4049 Lattes: http://lattes.cnpq.br/2444648587250384 E-mail: mauricio.guedes@ucp.br
} 
utiliza o método qualitativo e dedutivo, tendo como fonte primária e referencial teórica o trabalho "A Organização Nacional". Como resultado, entendeu-se que o realismo jurídico de Torres proporcionou, até hoje, novos instrumentos de aplicação de normas e marcos jurídicos à crítica do formalismo jurídico nos estudos de Teoria do Direito. Conclui-se que da época de Torres até 1988 foram muitas as discussões que marcaram o desenvolvimento da história constitucional brasileira que têm sua origem nos eventos ocorridos em âmbito nacional, conforme ensinado pelo autor.

Palavras-chave: Constituição de 1891; antiliberalismo; nacionalismo; antiformalismo; constitucionalismo.

\section{INTRODUCTION}

"We made Independence, and we are making our life, with borrowed clothes, alien political customs and texts from books that we decorate," says Alberto Torres in The National Organization (1982, p.251, our translation). The sentence expresses well Torres's proposal for legal realism, which is essentially a critique of ideas out of place, dissonant European and American's transplants with Brazilian society. Due to the need for more adequate solutions to the national reality, the book defends the review of the 1891 's Constitution as a reaction to the liberal politics of the first republic and the legal formalism, customizing a true Brazilian constitutional theory based on the realistic perspective. Thus, the hypothesis of the present article is that Alberto Torres' thought integrates the history of Brazilian constitutionalism by presenting an innovative proposal for legal solutions based on knowledge of Brazil's culture and people, a fact that proved to be fundamental for the development and consolidation of Brazil. National State, especially in the Vargas Era.

The research employs the deductive method from the analysis of books and articles, having as a theoretical framework the thinking of Alberto Torres consigned in the work The National Organization. The work has the general objective of demonstrating with the study of the legal realism of Alberto Torres, the relevance of this important movement of reaction to the legal formalism that emerges in Brazil at the beginning of the twentieth century and that is primordial for the development and consolidation of the contemporaneous national state.

The article is justified in that Alberto Torres' legal realism in Brazil went far beyond the classic constitutionalism that emerged in the late nineteenth century, as it provided new instruments for the application of legal norms and marks the critique of legal formalism within the Theory of Law's studies up to the present. In this way, we will start by exposing the 
existence of a typically national legal realism from Alberto Torres, seeking with this argument to demonstrate, even if punctually, its relevance to the formation of national legal thought. After contextualizing the basis of Alberto Torres' thought, we will analyze some of the points that we consider important in his constitutional project, in order to honor the richness of his thinking.

\section{LEGAL REALISM}

Although it is not possible to locate and delimit historical periods and their philosophical currents within a uniform setting in Western legal thought, it is certain that the late nineteenth, early twentieth century was marked by the strong criticism of legal positivism. If on the one hand the positivist rigidity and its dogmatic were of fundamental importance for the overcoming of the abuses that marked the Old Regime, offering the citizen the security so that it was no longer necessary to fear the wills practiced by the State, on the other hand, with the consolidation of Liberal revolutions beginning in the eighteenth century, there is a natural tendency to move law out of the positive field, transforming it into an essential value from which normative reality will derive its validity.

In fact, the law's worship as a primordial source of law turned out to be an insurmountable obstacle to the transformation of society's facts and ideas, so much that this new period was marked, to a greater or lesser extent, by the return to jusnaturalist thinking in Law's General Theory. It will be this reaction to the purely state character of law, which marked the rigidity of legal positivism, the main foundation for overcoming positivist fundaments and foundations, although it cannot lose sight of, however, that in this period it will be possible to find tough defenders contrary to this movement. Therefore, for example, in Brazil, the opinion of ultra-positivist's Francisco Campos would mark with his vision a different position:

The power to interpret the Constitution, finally and conclusively, would only be justified in attributing it, under democratic rule, to the judiciary, if the legal method were of a purely logical or deductive nature. The judiciary function would then be simply passive, the interpretation merely making explicit the content of the law. Such postulates are, however, hypotheses contrary to reality. Neither the legal method is purely logical nor the simply objective legal thinking. Interpretation, in turn, far from being passive and neutral, is a process of creation or active elaboration. When the law to be interpreted is the Constitution, the generality, the breadth, and the comprehension of the matter open up a vast field to the contribution of the interpreter who, though animated by the greatest of good faith, must pour in terms of his personal philosophy or his conception of life problems of the most vital interest to everyone and around whose expression, however precise, there is always a halo of indetermination, conducive to the 
choices of temperament, character, or will. In these circumstances, to attribute supremacy to the judiciary is to attribute it to the philosophy of judges. When it comes to national interests, the great powers of government, and the great public ends for which the government is intended, it is certainly more democratic, if not more accurate, to prefer to the philosophy and option of judges the option and philosophy of the Nation ( CAMPOS, 2001, p. 105, our translation).

It turns out, however, that this view would end up being thick drop in the course of the history of Brazilian constitutional thought, and, in this context, legal movements would criticize more and more, in the course of the twentieth century, the restrictive conception of law as a mere source of subsumption in the specific case. What should be emphasized, therefore, is that the conception and its relation between law and politics adopted by the national jurists of the first half of the twentieth century found their roots in the criticism of the formalism defended by legal positivism, having been founded in Brazil, from Alberto Torres, a new way of thinking about the role of the Constitution with reference to our peculiar social and political reality. From an antiliberal view that only the strong and secure state could guarantee Brazilian democracy, Alberto Torres' thought was concerned with the political and social interventions necessary for the effective consolidation of national unity. It is relevant to highlight, in this sense, that this question arises from the preface of his most important work, "The national organization", becoming the keynote of the debate he held:

Our history shows that we are capable of reform efforts. [...] Political errors and
international surprises aside, our country enjoys the privileged fortune of having
trouble, without difficulty, having the softest-hearted and wiser people, perhaps,
all over the world; only does not govern who does not know, or does not want to,
govern; and all its problems are summarized in this objective: to form, build and
develop the Nation, which is our people present-day and its offspring, people of
our races and those who come, cordially and fraternally, to live with us: the true,
the only Fatherland, for sincere hearts and for serene spirits. Political
disorganization destroys a nation more than wars. [...] We will then have to be
brave, aware and persevering to settle, consolidate and develop the organization.
"Brazilians - I wrote long years ago - have already proved that they can be soldiers
of the Republic; now they must prove that they also know how to be citizens.
"Brazil, I wrote it, also at about the same time, has, until today, been at the service
of the forms of government and the doctrines that it has adopted: the Republic
must, in turn, serve it "(Torres, 1982, p.57-58, our translation).

Alberto Torres is part of a group of Brazilian republicans who, at the beginning of the twentieth century, do not see in the liberal politics of the first republic the necessary foundation for the development of society. The study of Brazilian society and its peculiarities will serve as a background for the analysis that it will seek to perform, from a critical view of history and our social development. His work is still recognized today as a reference for nationalist thinking 
in Brazil, the result of the incipient understanding of the peripheral position that Alberto Torres consciously inserts our State, whose threat, represented by the misinterpretation of foreign doctrines, would result from the inadequacy of the political institutions created by Brazil national legislation to the reality of our people.

Interesting to observe, although not explicitly stated in Alberto Torres, the influence in Brazil of the legal movement that emerges in the United States of America during the twenties and thirties of the twentieth century. Imposing on social life political issues that until then had been denied to him, explains Lêda Boechat Rodrigues the exact relevance of the change effected by this movement in the American legal history:

Through extensive constitutional construction, based above all on the interpretation of the 14th Amendment, the Court became the arbiter not only of legal life, but of its own national political guidelines, by giving judicial solution to "not only morphological but substantially political" issues, according to the observation of Pontes de Miranda. Putting themselves in the position of declarers of a natural right above the Constitution itself, the judges of that court began to judge the superconstitutionality of the laws, rather than simply saying of their simple constitutionality or the jurisdiction of the legislature under the rule of law to adopt such or any measure. Laws were no longer declared invalid, for the most part, because they were incompatible with the texts of the Constitution and the processes it established, but because they were incompatible with the great principles superior to it. The main result of this supreme court control of the superconstitutionality of the laws at this stage was to emancipate it from the constitutional document, as it was not limited to applying strict legal rules to constitutional issues, but acted as a political department with governing powers (RODRIGUES , 1992, p.100, our translation).

American legal realism is not merely a reception of the classic philosophy of natural law, abandoned and discredited by the previous formalist period. On the contrary, although both movements have justice as a common element, the philosophy of natural law sought to find just law outside of positive law (and this characterized it), while for legal realism law and justice should be inferred and grounded within the positive right itself. These assumptions were fundamental to Alberto Torres's view of Brazilian law and the state whose verification, according to this author, derives from the very analysis of our history. In fact, our long history since the discovery in 1500 did not coincide with the recent political history of our country, so that Brazilian nationalism would be taking the first steps of its formation only at the beginning of the twentieth century, for Alberto Torres:

We made Independence, and we are making our life, with borrowed clothes, alien political customs and text from books we memorize. Our lack of sense and political groundwork is easy to demonstrate by simple application to anyone: to 
study the works of public men, from past times and today; and from this study it will soon appear that none of them dealt with the problems of our nationality, our society, our people, and our land (TORRES, 1982, p.251, our translation).

The development of the whole potentiality of the nation, outline of future's humanity as he himself defined it (TORRES, 1982, p.135), would depend on our people's awareness of the peculiar conditions of our land, our society and our environment to which we are inserted. In this way he argues:

\begin{abstract}
Moral's concern and Moral's exclusive action do not make Moral, because Moral is an abstraction, abstraction is realized only by resuming its place in the concrete synthesis of life: it follows that the moral anarchy of a disorganized society is not a sign of amorality or immorality; and that states of moral anarchy are not corrected by moral sanctions, or by purely moral action. No people have better moral stimuli and higher moral capacity than ours. Among the few, public life will have, however, reached the same state of apparent license and demoralization. It is a functional imbalance of moral criterion - the result of social disintegration. In these cases the reactions of "moralism" act as irritating or as unnerving; cause situations of terror or situations of stupor. Our reaction must be based on these data: full confidence in our indisputable morality, awareness of the real cause of our apathy, which lies in ignorance of our surroundings and ourselves, thus producing, by logical consequence, the extraordinary lightness of our spirit. The present Brazilian generation attends to the gestation of our nationality (TORRES, 1982, p.45, our translation).
\end{abstract}

It should also be highlighted the concern of Alberto Torres with the lack of political will of the Brazilian elite for the resolution of national problems, result of the mistaken concern with philosophical and legal questions studied from foreign theories that distanced our State from the problems proper to our land. and from a pragmatic view of the issues our society demanded:

The opinion regime depends on a certain degree of culture and a greater degree of civility. We have higher scale illustration than civilization. While our people count an immense mass of illiterates and, not including the indigenous, individuals still in state, material and moral, of savagery, the number of intellectuals is large and remarkable the elevation of their preparation. But in intellectualism the classical and ornamental form predominates over the intense and reasoning form. Knowing a lot and saying well is the ideal cultivated by most students: few are concerned with forming a practical philosophy and having an opinion on problems; almost all affect, on the things of politics and public life, the characteristic indifference of decaying cultures. Those who do not use culture as a simple weapon of personal combat remain on the ground of vague formulas and abstract theories, where they are not in danger of losing pleasantness and popularity. There is a purpose of visible abstention in the intellectual world that should initiate the discussion and give impetus to the currents of ideas. Brazilian intellectuals consider the preparation they have as a means of personal success, without attaching it to any duty, any responsibility for action and social direction (Torres, 1982, p. 47, our translation). 
In these terms, and to a higher extent than most of the defenders of this view of state, Alberto Torres was one of the greatest critics of the establishment of foreign institutes and institutions on national soil without the necessary adaptations to our peculiar organization, which, in his view, it really imported real subversion from the political system itself. It should be noted that this was the reality to which Alberto Torres was constitutionally inserted, as the transplantation of various US principles into the national legal context in 1891 disregarded the current post-monarchical system and the social and economic peculiarities in our country, leading in practice to misrepresentation in the application of these institutes.

The autonomy of the member nations characterized by self-organization, selfgovernment and self-administration meant pragmatically the breakdown of local and regional dependence with the center of political power, which led to the growth of forces not till then not so relevant in the Brazilian social scenario. It is precisely in this context of exclusion from the majority of the process of political participation, associated with the effective creation of mechanisms for maintaining the power of the dominant group, that the great obstacle that Alberto Torres's nationalism will seek to overcome will emerge and whose bases, under the point of view strictly legal, will imply the need for a structural change to the legislation then valid.

Like various movements that develop from the beginning of the twentieth century on the argument that law, as a social phenomenon, should be in empirical reality permeating the resolution of concrete cases, the revision of the Constitution, in this context, emerges as a foundation stone of the policy that Alberto Torres aims to see implemented in Brazil, and without which, in his opinion, all those interests that, in force since the beginning of the republican period, would not have led our country to the progress and development of democratic societies would continue to exist.

The knowledge of history becomes, in Alberto Torres, essential for the proper social and political development of Brazilian society, a fact that would be explored years later by Francisco José Oliveira Viana, one of his main disciples, from the sociological view of the law that would mark the national legal thought of this period. In establishing the classic distinction between utopian idealism and organic idealism, based on the lessons of Argentinian José Ingenieros, Oliveira Viana refines Alberto Torres' thinking by pointing out that political ideas must always be in line with societies as far as they are concerned which, in it, are realized as completely as possible, so that when they do not express a possible form of becoming, they are at best mere futile chimeras. According to the author, the "utopian idealism" would be 
characterized by the development of ideas that do not consider the data of experience, relegating the subjects who think this way to the condition of mere dreamers who do not deserve to be taken seriously by the true idealists (VIANA, 1939, p.12).

Organic idealism, in turn, is one that relies on experience, guided by observation of the people and their environment. This form, according to Oliveira Viana, in perfect harmony with the ideas of Alberto Torres, would never have been practiced in Brazil, since we would have deep and relevant roots in our political evolution under the predominance of utopian idealism:

This last form of [organic] idealism we never practiced; that has been our great sin of a hundred years. It is precisely this attachment to utopian idealism that is the only reason why we have not yet succeeded in achieving the definitive social and political organization of our people within the long span of more than a century of independence. This is exactly why, as we celebrate the centenary of our emancipation, we have not been able to display anything truly organized to the world:

a) nor our economic life;

b) nor our social life;

c) nor our political life (VIANA, 1939, p.13, our translation).

The understanding of this perspective will be of fundamental importance for the proper dimension that Alberto Torres will give to the law rather than the idea of law, a much broader concept that encompasses the effective knowledge of the empirical reality in which the norm will be applied. If, on the one hand, the express disposition of the law should be observed as a result of previous, general and abstract reasoning about a given situation, whose structuring bases could not be changed, Alberto Torres will go in a different direction to this formalism. admit the insertion of law as a prominent instrument within the political and social framework, and it is important to highlight its continuing concern to adapt the legal rule to what is actually found in the actual Brazilian reality.

And in this gap, exactly in the gap between constitutional reality and social reality, and from the idea that the Brazilian nation should be created by the state in order to create bonds capable of consolidating the country as a nation, is that Alberto Torres will defend the concepts and foundations of a realistic doctrine of law at the national level, based on legal assumptions that would guarantee, on the one hand, the defects of the democratic regime, and, on the other, the means of adapting it, together with the regime federative, our land and our people.

It is interesting to note that this view was adequate to Alberto Torres' sense of national unity, which aims at the consolidation of the state as supreme holder of sovereignty, as it provided the Constitution with far-reaching, far from imperfections and inconsistencies 
resulting from excessive importation of foreign principles, shaping its text to the practice and the national reality. Commenting on the values that marked the elaboration of his draft's revision of the Constitution of 1891, Alberto Torres demonstrates his concern with social reality and the practical purposes underlying the normative text itself, essential vectors for the proper application of the legal norm:

The word "constitution, involving the idea that this law is the expression of national life, has the value of its physiological meaning: it is a political predication made to point out that it is a law adapted to social reality, obeying practical purposes, not only originally inspired by a certain order of general and permanent objects, but originally dominated by the scope of its application to the evolutionary development of society. Politics is the bond that dominates the body of the constitution and links its dispositions with each other and its intelligence to the movements of society, the people and the facts. Hence the supremacy in the interpretation of this broad and high meaning over the express, isolated, and lateral intelligence of the law (Torres, 1982, p. 216, our translation).

The evolution of society and its paradigms will permeate a significant part of Alberto Torres' work, acting as a driving force that will guide the interpretation of the Constitution by the operator of the law, and whose purpose is, in fact, to place the State at the primacy of the construction of the Brazilian nation.. In presenting and substantiating the proposal for legislative amendment of the Constitution, Alberto Torres will argue that the application of the law to the concrete case should correspond much more to the facts that occurred than to the theoretically thought law, common ground to the realistic doctrines that argued that only with this position would it be adequately safeguard the true content of the legal rules. In this sense relevant passage of his work:

\footnotetext{
Among us, the wording of the Constitution and the constitutional interpretation, according to the verbal and analytical criteria we inherited from our ancestors and the first educators of our spirit, make each particular disposition an isolated, strong and efficient principle, against the express set of constitution, the principles implicit in its clauses, and the ideas which, logically preceding the reasons for the express dispositions and the implicit principles, necessarily dominating them, form the virtual essence - not only the spirit in the common sense of legal language - but the own driving force, active and vital, of the code of life of a people (Torres, 1982 , p. 215, our translation).
}

The relevance of the social question brought by Alberto Torres also permeated the idea of law and justice, so that the application of the legal norm to the concrete case should also have as a parameter the convenience of the public interest and the imperatives of social order. Equally, part of Alberto Torres' criticism presupposes, in the field of law, the overcoming of 
the positivist paradigms of interpretation of the legal norm, making the teleological, systematic and historical-evolutionary methods prevail:

The spirit of our legislators, judges and politicians, educated in the methods of legal analysis - almost exclusive criterion, in the elaboration and interpretation of Private Law, and the only method practiced in the academies and the forum, on texts that can be examined and applied alone or, at least partial - it has not yet become fond of the character of this superior law, the norm of a collective personality, which, precisely because it contains the public law of the entire nation, forms a complex, general law whose object is embodied in the territory and in society, encompassing them as in a system of concentration and harmony, where each special principle is as if the bearer, for the particular cases, of its larger thoughts, reaching the individual only by reflex effect and by understanding and where it does not separate the whole in articles and paragraphs, but to communicate to the various public agencies the very life of society: a global law, and In short, it is based on basic, general and fundamental principles, which, if not properly instilled in it, give it universal reach over all parts (TORRES, 1982, p. 215-216, our translation).

Pioneer, this study initiated by Alberto Torres was followed by a series of authors who sought to understand Brazilian society from the analysis of our peculiar social and political issues, and it is worth mentioning, among others, as seen above, the figure of Oliveira Vianna, fan of the realism and great enthusiast of this movement in Brazil:

Torres and I, what we did in relation to the scientific knowledge of our evolution and social formation, from the point of view especially of the evolution of political institutions and state structure, consisted of this methodological novelty here: considering the problems of the state or rather, the political and constitutional problems of Brazil, not just simple problems of doctrinal or philosophical speculation as it was then done and what Rui's method was; but as objective problems, linked to the cultural reality of the people and, consequently, as problems of behavior of the Brazilian man in the Brazilian society of "behavior", in the strict and technical sense given to this expression by the American sociologists (as, for example, Ralph Linton and Donald Pierson, in books that are today, in our country, in the hands of all social science scholars (VIANNA, 1999, p.399-400, our translation).

What we want to demonstrate in this first part of the present study is that the legal realism of Alberto Torres presupposed the pragmatic application of the legal norm from the circumstances that permeated the concrete case, inaugurating a new way of thinking the study of the law, notably the constitutional law, whose implications can be found in the various political and social spectra of contemporary law. 


\section{1'S CONSTITUTION REVIEW}

In addition to discussions about the role of the state and the constitution in the development of national society, Alberto Torres presented a proposal to revise the 1891's Constitution in order to shape the Magna Carta from our peculiar social and political issues. From the full reading of the proposals presented by Alberto Torres, it is quite clear his intention to structurally modify the 1891's Constitution without, however, making a movement of constitutional rupture, something that would resemble what Jorge Miranda calls constitutional transition and that would justify the broad amendment of the constitutional text:

The constitutional transition is the passage from one material constitution to another with observance of constitutional forms, without rupture, therefore. It changes the material constitution but remains the instrumental constitution and eventually the formal constitution. When given by the review process, it may consist of express constitutional precepts, as mentioned. At other times, it may simply result from the use of the general process of constitutional revision, certain requirements being met, for the removal of fundamental principles or for the substitution of political regime. This is what happens when, through the review process, material, explicit or implicit limits equivalent to such principles are departed (MIRANDA, 2015, p.259-260, our translation).

Within this context, and permeating the whole set of constitutional changes defended by Alberto Torres, arises the criticism of the positivist method as defended in the late nineteenth century, revealing this practice, in the author's view, as a mere instrument of agency available of those who sought to interpret legal norms at their own convenience and who ultimately restricted what was most important at the heart of the constitutional text: the transformation of society. The constitution conceived by Alberto Torres presupposes its effective practical applicability, which, in addition to the legal norm in the formal sense, must represent the true spirit of the Brazilian people:

The Constitution, as a practical law, cannot be a formal law: it is a true political script; a synthesis, not only of the methods, processes and instruments necessary for national progress, but also of their great ends and objectives dictated by the nature of their land and its people. Formulated in this spirit, it avoids, on the one hand, agency, and enables the power to carry out the burdens of government. The idea that constitutional law is a national law - the source of all national laws and supreme national law - is firmly engraved in the minds of the spirits of the present and of the future must be stated and the content of their solutions fixed (Torres, 1982, p. 249, our translation).

Beginning the analysis of the constitutional revision text itself, Torres recommended the inclusion of a specific provision that should clarify the political role and the practical end of the 
legal norms in general, suggesting that this issue should become part of the constitutional text itself. Unquestionable pragmatic trait proper to realistic doctrines, something at least unusual for a country that is not concerned with establishing the means and methods of interpretation of legal norms, whether constitutional or not, proposed Alberto Torres to include the following article in our Magna Carta, in which it teleologically underscores the need for legal norms to promote the ends of society and individual life in our state:

Article 81 In the interpretation of the Constitution and the laws, Judges, legislators and all those to whom their application is responsible shall have in view the following principles, rather than other legal rules of interpretation: I. The Constitution is a political law, of practical purposes, founded on concrete social objects, and intended mainly to keep the general and permanent interests of the country linked, harmonically and organically; II. The basis of their interpretation is the practical and social end that their whole and its principles are intended to accomplish; III. Neither the literal meaning of the text, nor the source, origin, school, or doctrinal tradition to which it is attached, will argue for any interpretation contrary to its practical destiny and social purpose; IV. By a historical element of interpretation is meant, not only, nor principally, the debates, opinions, legislative speeches, and more preparatory acts of lawmaking, but above all, the reason for legislating and the inspiring interests, relations, and facts of the legislative principles, and their permanent and general ends;

V. Being the object of the Constitution and the laws to promote the ends of society and individual life, its principles must be understood in the most favorable sense for such ends: the development and progress of society and the interest and prosperity of individuals; VI. The practical element of interpretation must be understood in relation to the general and permanent welfare of society and the individual, the development and progressive succession of social and legal facts and phenomena, and never to accidents, isolated facts, and partial and momentary interests. Single paragraph. In drafting the Laws, legislators should also have, in view of the principles of this article, to the extent applicable to it. (Torres, 1982, p. 322, our translation).

From a structuring point of view, the proposal for constitutional revision created by Alberto Torres defends the modification of the foundations of Brazilian federalism, which should be in accordance with our national history. The change of the name of the Brazilian State from United States of Brazil to Federative Republic of Brazil does not present itself to Alberto Torres as a mere change of the referred denomination in the theoretical sense, but in recognition of the lack of capacity of certain member states - which would be referred to as autonomous provinces controlled by the political sovereignty of the Union - in exercising their respective constitutional functions. 
The clause "and the political sovereignty of the Union", which is added to the same paragraph, is intended to indicate, by means of a general formula, that, as a body of the Nation and the People, invested with the guard and defense of the general interests and permanent of the Brazilian land and its inhabitants, and charged with caring for the present, for society and for individuals, and, in the future, for the conservation and improvement of the territory, its productivity and wealth, for the life and progress of races and nationality, the Union cannot recognize, in the particular groupings of the country, interests, ends and objectives contrary to its superior design and its solemn and unquestionable mandate. Their "sovereignty" is not limited by the circumscription autonomy of provinces and municipalities, but by the interests of the individual, society, nation and species (Torres, 1982, p.221, our translation).

The peculiar organs of the national sovereignty and their respective compositions in the legislative proposal indicated by Alberto Torres are the legislative power, the executive, the coordinator and the judiciary, being recognition of the "incapacity of the masses" for the proper functioning and articulation between such powers. For the exercise of democracy and thus the creation of a system that would be able to alleviate the shortcomings of this regime by adapting it to our land and our people.

The legislative power would continue to be bicameral, certain that the composition of the chamber of deputies and the senate should be more appropriate to the Brazilian homeland reality. In fact, while the House of Representatives would be made up of 125 members, half of this number being elected by electoral districts, one quarter by states, and the other quarter by country, the Senate would consist of three groups of representatives elected as follows: $1^{\circ}-$ five senators over 35 , appointed from all over the country; $2^{\circ}-21$ citizens over 35 years appointed by the Provinces and the Federal District; and 3 - 37 citizens, over 35, appointed by the following groups of voters: three senators, by priests of the Catholic clergy; one for the priests of the other religious confessions; one by the Brazilian Positivist Church and Apostolate; two, by charitable, mutual and non-religious moral associations of limited membership recognized by the government; one by the non-religious voters; three by governmentrecognized congregations, academies, scientific, literary, and artistic associations of limited membership, and secondary and primary school teachers; two by magistrates and lawyers; two by doctors, pharmacists and dental surgeons; two by engineers and industrialists; five by farmers who cultivate export products; six by farmers and producers in general of consumer goods in the country; one by the urban workers; three by agricultural workers; two, by bankers, traders, brokers and people who work in similar professions: two by civil and military officials of the Union, provinces and municipalities; one, by journalists and writers of other advertising agencies. 
The composition of the National Congress as described above would tend, in Alberto Torres' view, to guarantee the most complete reality possible, considering him the "exponent of the mentality of the country, where all the organs of spirit and national activity have a vote, to ascertain, with careful examination of the opinions and interests and in the light of the social orientation that the Constitution determines" (TORRES, 1982, p. 254, our translation).

Moving away from the idea of party government as established by the 1891 Charter, Alberto Torres' draft amendment to the Constitution would surpass, in the author's view, the ideal of the representative system to ensure representation based on the interests and ideas of society so heterogeneous considering the national vicissitudes. Executive power would be exercised by the president and vice president of the republic, elected by a special electorate of which would be part of the senators and federal deputies, the provincial presidents, the members of the Legislative Assemblies; the members of the national council, the directors of the court of auditors and the prosecutors and union delegates in the provinces; members of the supreme court of justice, members of the courts of second instance and magistrates and prosecutors; the lenses and teachers of higher and secondary schools; the directors of services and teachers of the National Problems Study Institute, which was created in the proposal with the purpose of making the study of the practical problems of the Brazilian land and nationality, its inhabitants and its society and composed of Brazilian citizens who have scientific degrees of any kind and those with sufficient intellectual preparation to assist them; members of corporations and associations of scientific, artistic, professional, social, moral or trade union purposes, of limited number of members, recognized by the Government, who take part in the election of Senators; members of trade union committees, organized with limited membership, to represent the classes that are to be part of the election of senators. Here also remains the concern of Alberto Torres to make the president and vice president of the republic representatives of groups able to think social reality from the Brazilian peculiarities.

The judiciary, in turn, would be solely linked to the union, with the highest court having the supreme court of justice and as many federal judges and courts distributed in the country as the congress establishes, with the magistrates having the complex task of politically interpreting the Constitution the purpose of guaranteeing the concrete social objects and the general and permanent interests of the country. For no other reason would the inclusion of a specific article in the Constitution entitled Interpretation of the Laws, in the midst of which judges, legislators, and all those in charge of applying the constitutional text should assume that "Constitution is a political law, with practical purposes, founded on concrete social objects, and intended mainly 
to keep the general and permanent interests of the country linked, harmonically and organically "(TORRES, 1982, p. 268, our translation).

Similarly, the basis of interpretation of the law could be none other than "the practical and social end which its whole and its principles are intended to achieve" (TORRES, 1982, p. 269, our translation), so that "neither the literal meaning of the text, nor the source, origin, school, or doctrinal tradition to which it is linked, will serve as an argument to any interpretation contrary to its practical destiny and its social end" (TORRES, 1982, p. 269, our translation). Considering the instrumentality of the Constitution in the attainment of the ends of society and of individual life, "its principles must be understood in the most favorable sense to those ends: the development and progress of society and the interest and prosperity of individuals" (TORRES, 1982, p. 269, our translation), all in accordance with the general and permanent welfare of society and the individual.

Still within the state organization outlined by Alberto Torres there would be the need for the creation of a fourth power, the coordinating power, in order to strengthen, from its different organs and representativeness, the proper practice of government acts:

Finally, the creation of the Coordinating Power crowns these provisions - all aimed at strengthening governmental action, linking the institutions of the country in solidarity and establishing continuity in the pursuit of national ideals, to "realize", in short, the sovereignty of the law, democracy, the republic, autonomy and the federation - with one body, whose function will be to concatenate all the apparatuses of the political system, as mandate of the entire nation - of today's nation, as of tomorrow's nation - before their delegates (Torres, 1982, p.252, our translation).

The coordinating power would be composed for Alberto Torres from the following organs: the national council, made up of a special electorate of which the president would be part, that would have the votes corresponding to three quarters of the number of members of the council, the vice-president with a quarter of the votes, the council members themselves, members of the national congress nominated by both houses, ministers of the supreme court of justice, and directors of the institute for the study of national problems, and one federal prosecutor in each province, appointed by the National Council, one federal delegate in each municipality, appointed by the National Council, and one Union representative and mayor in each district and block, respectively.

With its own powers to moderate the relationship between the other powers, it would be up to the coordinating power, among other activities, to conduct the electoral process, to declare, generally and compulsorily, the unconstitutionality of the laws and acts of federal 
powers, provinces and municipal authorities, representation of any authority or citizen or ex officio, which would imply true abstract control of constitutionality then nonexistent in the light of the 1891's Charter, and, finally, to verify the legality and accuracy of the application of public money and budgetary matters, that would be carried out by a court of auditors with constitutionally established powers.

Finally, within the narrow purpose that was intended with this article, it is important to note the readjustment of the Brazilian federal pact defended by Alberto Torres with the end of the member states and the replacement by autonomous provinces, these with restricted performance so that, together with the municipalities, would adequately compose the role of federative entities from our peculiar formation process. It does not seem to be coherent with the thought of Alberto Torres the originally defended idea that the Constitution of 1891 would elevate the member states to sovereign entities, which would go against the defense of the national interests defended by the referred author during his study. Simply a means of better serving the interests of local people, autonomy could not become an instrument, in Alberto Torres' view, of limiting general power, but a means of consolidating true national aspirations.

\section{CONCLUSION}

From all that has been exposed, what can be observed is that, beyond the mere limit of legal issues, the movement of legal realism found in Alberto Torres emerges as a paradigm for the construction and consolidation of the state, and it is important to emphasize the peculiar relevance of this issue for the development of a typically Brazilian political-constitutional thinking. From the pragmatic view developed by Torres and debated in this article, we find the absence of adequate knowledge of our reality, which matters in the emptying of our sovereignty, bringing lights and instruments that could mark and modify the study of the theory of law in the constitutional homeland system.

What is intended to be highlighted in this article is that, in the space between constitutional reality and social reality, a movement led by Alberto Torres flourished in early twentieth-century Brazil, which turned the consolidation of society itself into the center of the theory's concern of the law, defending, from their respective social interests, questions related to justice and equity that broke with the formalist paradigms then in force. It would be within this realistic movement advocated by Alberto Torres that jurisdiction would serve the purposes of a new society, preparing it for the beginning of the third millennium. 
From ideological matrices that were concerned with the social order, the movement of Brazilian legal realism ended up perfectly filling the values and paradigms of our society, especially the one that develops after Alberto Torres' death. It is concluded that, differently from what is still affirmed by a part of contemporary constitutional theorists, from the time of Alberto Torres until 1988 there were many discussions that marked the development of Brazilian constitutional history that have their origin in the events that occurred at the national level, as teaches the author.

\section{REFERENCES}

CAMPOS, Francisco. O Estado Nacional: sua estrutura, seu conteúdo ideológico. Brasília: Senado Federal, Conselho Editorial, 2001.

MIRANDA, Jorge. Teoria do estado e da constituição. 4.ed., Rio de Janeiro: Forense, 2015.

RODRIGUES, Lêda Boechat. A corte suprema e o direito constitucional brasileiro. 2 ed., Rio de Janeiro: Editora Civilização Brasileira, 1992.

TORRES, Alberto de Seixas Martins. A organização nacional. Rio de Janeiro: Editora Universidade de Brasília, 1982.

VIANNA, Francisco José Oliveira. Instituições política brasileiras. Brasília: Conselho Editorial do Senado Federal, 1999.

O idealismo na Constituição. Rio de Janeiro: Companhia Editora Nacional, 1939.

Trabalho recebido em 28 de agosto de 2020

Aceito em 04 de dezembro de 2020 